\title{
PERBANDINGAN TINGKAT KEBAHAGIAAN ANTARA GENERASI SANDWICH DAN NON-GENERASI SANDWICH
}

\begin{tabular}{|c|}
\hline Ferlistya Pratita Rari ${ }^{1}$, Jamalludin $^{\mathbf{2}}$, Putri Nurokhmah \\
\end{tabular} Diterima: Januari 2021; Disetujui: Juli 2021

Abstract. The indicators of population welfare are not only measured in monetary terms but also in subjective well-being or happiness. Research on happiness has been done a lot, both in developed and developing countries. However, no research discusses the happiness level of the sandwich generation. This study aims to determine the differences in happiness between the sandwich generation and the non-sandwich generation based on the number of family members covered, leisure time, health conditions, and monthly household income. This research was conducted by collecting data on two groups: sandwich generation and non-sandwich generation, consisting of 158 survey respondents in 4 provinces in Indonesia: Special Capital Region Jakarta, Aceh, West Java, and Central Java, and three in-depth interview informants. This study combines the quantitative method (path analysis regression) and the qualitative method (in-depth interview). The findings in the study are: (1) There is no difference in the level of happiness between the sandwich generation, and non-sandwich generation, (2) Variables that directly affect happiness are health and income, while the number of family dependents and leisure time has no direct effect, (3) The existence of parents in the extended family is not considered as a burden for the sandwich generation.

Keywords: happiness, sandwich generation, subjective well-being.

Abstraksi. Indikator kesejahteraan penduduk tidak hanya diukur berdasarkan moneter, tetapi juga kesejahteraan subjektif atau kebahagiaan. Penelitian mengenai kebahagiaan sudah banyak dilakukan, baik di negara maju maupun berkembang. Namun, belum terdapat penelitian yang membahas tentang tingkat kebahagiaan generasi sandwich. Penelitian ini bertujuan untuk mempelajari perbedaan tingkat kebahagiaan generasi sandwich dan non-generasi sandwich berdasarkan jumlah anggota keluarga yang ditanggung, waktu luang yang dimiliki, kondisi kesehatan, serta jumlah pendapatan rumah tangga per bulan. Penelitian ini dilakukan dengan mengumpulkan data terhadap 2 kelompok: generasi sandwich dan non-generasi sandwich yang terdiri dari 158 responden survei di 4 Provinsi di Indonesia, yaitu Daerah Khusus Ibukota (DKI) Jakarta, Aceh, Jawa Barat, dan Jawa Tengah dan 3 orang informan. Penelitian ini mengombinasikan metode kuantitatif (analisis regresi jalur) dan kualitatif (wawancara mendalam). Temuan dalam penelitian adalah: (1) Tidak terdapat perbedaan tingkat kebahagiaan antara generasi sandwich dan non-generasi sandwich, (2) Variabel yang berpengaruh langsung terhadap kebahagiaan adalah kesehatan dan pendapatan, sedangkan jumlah tanggungan keluarga dan waktu luang tidak berpengaruh langsung, (3) Keberadaan orang tua tidak membuat generasi sandwich merasa terbebani.

Kata kunci: generasi sandwich, kebahagiaan, kesehatan, kesejahteraan. 


\section{PENDAHULUAN}

Sustainable Development Goals (SDGs) atau Tujuan Pembangunan Berkelanjutan (TPB) menjelaskan bahwa kesejahteraan penduduk tidak hanya diukur dengan ukuran moneter, tetapi juga kesejahteraan subjektif atau kebahagiaan. Mengacu pada Easterlin (1995), kebahagiaan adalah ukuran perasaan kesejahteraan secara keseluruhan atau kesejahteraan subjektif. Sementara itu, Veenhoven (1995) dalam Behavior \& Abdel-khalek (2015) mendefinisikan kebahagiaan atau kepuasan hidup sebagai sejauh mana seseorang menilai kualitas hidupnya dengan baik.

Frey \& Stutzer (2000) menyebutkan terdapat beberapa faktor penentu kesejahteraan dan kebahagiaan. Yang pertama, faktor kepribadian dan demografis, misalnya usia, jenis kelamin, kewarganegaraan, tingkat Pendidikan formal, pengaturan keluarga dan status pekerjaan individu. Yang kedua adalah faktor mikro dan makro, misalnya individu berstatus sebagai penganggur, situasi pendapatan rumah tangga atau kesetaraan pendapatan dan tingkat inflasi. Yang ketiga adalah kondisi kelembagaan atau konstitusional dalam suatu ekonomi masyarakat. Sementara itu, pada Hari Kebahagiaan Internasional yang pertama kali dirayakan pada tahun 2013, The Organization of Economic Cooperation and Development (OECD) merilis pengukuran kebahagiaan melalui pendekatan tiga dimensi yaitu kepuasan hidup, makna hidup dan perasaan. Determinan dari kebahagiaan itu sendiri antara lain, pendapatan, status kesehatan, kontak sosial, status pekerjaan, tipe kepribadian, dan budaya.

Survei pengukuran tingkat kebahagiaan telah banyak diterapkan di berbagai negara, baik negara maju maupun negara berkembang. Di Inggris misalnya, terdapat
Oxford Happiness Questionnaire (OHQ) yang merupakan pengembangan dari The Oxford Happiness Inventory (OHI) yaitu sebuah pengukuran untuk kebahagiaan pribadi yang dikembangkan di Universitas Oxford sejak akhir tahun 1980-an. (Hills \& Argyle, 2002). Sementara itu, di Indonesia terdapat survei longitudinal Indonesian Family Life Survey (IFLS). Selain IFLS, terdapat pula survei yang dilakukan oleh Badan Pusat Statistik (BPS), yaitu Survei Pengukuran Tingkat Kebahagiaan (SPTK).

SPTK mengadopsi Organisation for Economic Co-operation and Development (OECD) Better Life Index yang mengukur tingkat kebahagiaan dalam tiga dimensi yaitu kepuasan hidup, perasaan, dan makna hidup. Berdasarkan data SPTK 2014-2017, tingkat kebahagiaan di Indonesia meningkat $1,83 \%$. Namun semakin tua penduduk Indonesia, semakin menurun tingkat kebahagiaannya, di mana kebahagiaan pada penduduk usia 41-64 tahun lebih rendah dibanding mereka yang berusia kurang dari 40 tahun. Temuan lain dari SPTK adalah bahwa semakin banyak jumlah anggota rumah tangga, maka akan semakin rendah tingkat kebahagiaannya. Kedua indikator tersebut (usia pertengahan tahun dan jumlah anggota rumah tangga) merupakan dua hal yang menjadi ciri khas dari pengklasifikasian generasi sandwich.

Generasi sandwich merupakan orangorang (umumnya berusia middle aged) yang memiliki peran ganda, yaitu bertanggung jawab terhadap anaknya yang masih tinggal bersama di rumah dan juga bertanggung jawab atas orang tua serta mertuanya (Shclesinger \& Raphael, 1993; Marts, 2013). Posisi yang berada di antara dua generasi membuat seseorang diibaratkan seperti sandwich.

Pada awal studi mengenai generasi sandwich, yaitu pada tahun 1981 di 
California, terdapat batasan subjek penelitian tentang generasi sandwich dengan kategori usianya, yaitu perempuan yang berada pada kategori middle age (berada pada kisaran umur 45-65 tahun). Studi selanjutnya yang dilaksanakan di negara Toronto tidak membatasi usia individu untuk mengklasifikasikannya ke dalam generasi sandwich, tetapi juga menerapkan batasan khusus yaitu keberadaan anak dengan usia di atas 18 tahun dan memiliki tanggung jawab untuk menjaga/ merawat orang tua dan/atau mertuanya (Shclesinger \& Raphael, 1993; Miller, 1981). Sementara itu, Hernandez et al., (2019) mendefinisikan generasi sandwich sebagai individu yang berada dalam kondisi fit untuk bekerja dan "terperangkap" antara tanggung jawab keluarga dengan tanggung jawab profesional. Generasi sandwich membagi sumber daya mereka untuk anak dan orang tuanya yang telah memasuki usia lanjut (Broady, 2019). Pada perkembangannya selama beberapa tahun terakhir, seiring dengan generasi milenial yang mulai berada di masa untuk merawat orang tuanya yang menua, maka dinamika definisi "generasi sandwich" bertransisi meluas menjadi "kelompok generasi sandwich" yang terdiri dari empat generasi keluarga yang saling ketergantungan satu sama lain dalam beberapa hal (Migliaccio, 2019).

$$
\text { Shclesinger \& Raphael }
$$
menjelaskan bahwa keberadaan status generasi sandwich tidak terlepas dari adanya kewajiban menjaga keluarga di luar keluarga intinya. Juin (2015) di Perancis menemukan bahwa tanggung jawab merawat orang tua memiliki efek negatif terhadap tingkat kesehatan, terutama apabila tanggung jawab perawatan tersebut adalah intensif (lebih dari 20 jam per minggu). Menurut Maon et al (2016) dalam
Bt Ahmad et al., (2018), mereka menghadapi konflik ketika tanggung jawab keluarga dan tuntutan pekerjaan harus diselesaikan secara bersamaan. Lebih lanjut, potensi konflik ini semakin tinggi pada kelompok individu berpendapatan rendah dan mempengaruhi kualitas hidup generasi sandwich dalam hal tingkat kepuasan terhadap pekerjaan dan keluarganya (Ahmad et al., 2016 dalam Noor \& Isa, 2020).

Lebih lanjut, status generasi sandwich membuat seseorang memiliki jumlah tanggungan keluarga yang lebih banyak apabila dibandingkan dengan non-generasi sandwich. Jumlah tanggungan keluarga yang lebih banyak tersebut menyebabkan generasi sandwich memiliki kewajiban finansial yang cenderung lebih tinggi dan proporsi waktu luang yang lebih sedikit dibanding non-generasi sandwich. Padahal, menurut Varian (2010) dalam Teori Standar Ekonomi, kebahagiaan individu diturunkan dari kepuasan, yang dipengaruhi oleh pendapatan dan waktu luang. Selain itu, status sebagai generasi sandwich juga memberikan dampak negatif terhadap kondisi pernikahan, kesehatan, menimbulkan stres, kecemasan, dan kesedihan (Solberg et al., 2014). Sejalan dengan hasil studi tersebut, penelitian Hopps et al., (2017) di Amerika Serikat menemukan bahwa kelompok individu yang memiliki tanggung jawab merawat orang tua lebih banyak yang merasa tertekan apabila dibandingkan dengan yang tidak memiliki tanggung jawab serupa.

Determinan yang memengaruhi tingkat kebahagiaan pada studi empiris terdahulu tersebut melatarbelakangi penelitian ini, dimana hingga saat ini penelitian yang membahas kebahagiaan secara khusus pada generasi sandwich masih jarang ditemukan di Indonesia. 
Penelitian ini bertujuan mengidentifikasi perbedaan

untuk kebahagiaan antara generasi sandwich dan non-generasi sandwich berdasarkan: (1) jumlah anggota keluarga yang ditanggung; (2) waktu luang yang dimiliki; (3) kondisi kesehatan; dan (4) jumlah pendapatan per bulan. Lebih lanjut, mengacu kepada tujuan penelitian, maka hipotesis dalam penelitian ini adalah terdapat perbedaan tingkat kebahagiaan antara Generasi Sandwich (GS) dan Non-Generasi Sandwich (NGS) berdasarkan: (1) jumlah anggota keluarga yang ditanggung; (2) waktu luang yang dimiliki; (3) kondisi kesehatan; dan (4) jumlah pendapatan per bulan.

\section{METODE PENELITIAN}

\section{Desain dan Sampel}

Metode penarikan sampel yang digunakan adalah non-probablity sampling. Metode ini dipilih karena ketiadaan kerangka sampel yang bisa dijadikan acuan. Instrumen yang digunakan adalah kuesioner daring yang disebarkan melalui media sosial seperti whatsapp, twitter, dan facebook. Penyebaran link kuesioner berdasarkan pada kemudahan jangkauan peneliti melalau jejaring relasi. Pengumpulan data dilakukan selama 21 hari pada periode akhir Oktober hingga pertengahan November 2019.

Unit analisis dalam penelitian ini adalah individu yang: (1)berstatus menikah/cerai hidup/ cerai mati; (2)bekerja dan/atau memiliki pasangan yang bekerja; (3)sudah memiliki anak; (4) bertempat tinggal di Provinsi DKI Jakarta, Jawa Barat, Jawa Tengah atau Aceh. Dari 158 responden, dilakukan filter dengan kriteria keberadaan tanggungan berupa anak dan orang tua sekaligus, untuk mendapatkan sampel generasi sandwich. Hasil filter data menunjukkan bahwa terdapat 32 responden yang masuk dalam kategori generasi sandwich.

\section{Ukuran}

Ukuran kebahagiaan pada penelitian ini merujuk pada kuesioner Oxford Happiness Inventory (OHI). Kuesioner ini terdiri dari 29 indikator, terdiri dari pernyataan positif dan negatif. Skala pengukuran ini terdiri dari 6 pilihan jawaban, skor 1 menyatakan sangat tidak setuju dan skor 6 menyatakan sangat setuju. Kategorisasi dari variabel kebahagiaan menggunakan cutting point dari median skala penilaian. Jika median penilaian responden $\leq$ median skala penilaian, maka masuk ke dalam kategori kurang bahagia dan jika median penilaian responden > median skala penilaian, maka masuk kategori bahagia.

Ukuran dari waktu luang adalah banyak waktu yang digunakan selain untuk bekerja dalam seminggu (Wang \& Wong, 2014), mengurus rumah tangga, dan sekolah. Rujukan waktu dari variabel waktu luang adalah dalam rentang sepekan terakhir dan dinyatakan dalam jam. Ukuran dari jumlah tanggungan adalah banyaknya anggota rumah tangga yang tidak berkontribusi dalam pendapatan dan pembiayaan kebutuhan rumah tangga. Ukuran dari pendapatan rumah tangga adalah rata-rata pendapatan rumah tangga per bulan dalam periode setahun terakhir. Ukuran dari kesehatan adalah median skor dari item mengenai kondisi kesehatan responden.

\section{Metode Analisis}

Metode analisis yang digunakan dalam penelitian ini terdiri dari analisis deskriptif, inferensia dan kualitatif. Analisis deskriptif yang digunakan berupa tabulasi silang, analisis inferensia yang digunakan adalah uji beda dua rata-rata/ t-test dan analisis jalur, sementara untuk analisis kualitatif yang digunakan adalah indepth interview. 


\section{Analisis Tabulasi Silang}

Hubungan antar variabel secara deskriptif dapat dilihat melalui tabulasi silang antar variabel tersebut. Dalam penelitian ini analisis tabulasi silang dilakukan untuk setiap variabel bebas terhadap variabel terikat. Kecenderungan unit analisis untuk bahagia berdasarkan kriteria dari variabel bebasnya dapat diketahui melalui nilai rasio kecenderungan yang tidak disesuaikan/ unadjusted odds ratio. Unadjusted odds ratio merupakan perbandingan dari persentase unit analisis yang diperhatikan dengan persentase unit analisis yang dibandingkan. Unadjusted odds ratio berguna untuk melihat secara kuantitatif berapa kali kecenderungan unit analisis dalam kategori variabel bebas untuk terpapar dalam kategori di variabel terikat.

\section{Uji Beda Dua Rata-Rata Sampel Independen/ T-Test}

Uji beda dua rata-rata sampel independen digunakan untuk melihat apakah ada perbedaan tingkat kebahagiaan antara generasi sandwich dan non-generasi sandwich. Formula dari uji beda dua ratarata adalah sebagai berikut:

$t_{\text {obs }}=\frac{\text { mean kebahagiaan } G S-\text { mean kebahagiaan NGS }}{\text { Standard error perbedaan rata rata kebahagiaan kedua sampel }}$

Pada penelitian ini uji beda dua rata-rata sampel independen dilakukan dengan dua skenario. Skenario pertama adalah dengan menguji secara langsung antara 32 sampel generasi sandwich dengan 126 sampel nongenerasi sandwich. Skenario kedua adalah dengan cara memilih secara acak dari 126 sampel non-generasi sandwich sebanyak 32 sampel untuk kemudian dibandingkan dengan 32 sampel generasi sandwich. Skenario kedua dilakukan untuk mengantisipasi jika ketimpangan jumlah sampel antara dua unit yang dibandingkan sensitif terhadap penghitungan uji beda dua rata-rata.

\section{Analisis Jalur}

Analisis jalur merupakan pengembangan dari model regresi. Analisis jalur dapat melihat pengaruh secara langsung dan tidak langsung dari suatu variabel terhadap variabel lain. Pada penelitian ini analisis jalur hanya dilakukan pada mereka yang generasi sandwich, untuk lebih mendalami variabel yang secara langsung dan tidak langsung memengaruhi kebahagiaan generasi sandwich. Analisis jalur dapat melihat pengaruh langsung dari jumlah anggota rumah tangga, pendapatan, kesehatan, dan waktu luang terhadap tingkat kebahagiaan dari generasi sandwich, begitu juga pengaruh tidak langsung dari jumlah anggota rumah tangga dan pendapatan terhadap tingkat kebahagiaan dari generasi sandwich.

Tahapan awal dari analisis jalur adalah membangun diagram jalur. Diagram jalur dapat diartikan seperti mind mapping, karena berangkat dari suatu teori. Asumsi dari analisis jalur yang harus dipenuhi adalah distribusi dari variabel normal secara multivariat, model yang dihipotesiskan harus valid, dan skala pengukuran dari variabel adalah interval.

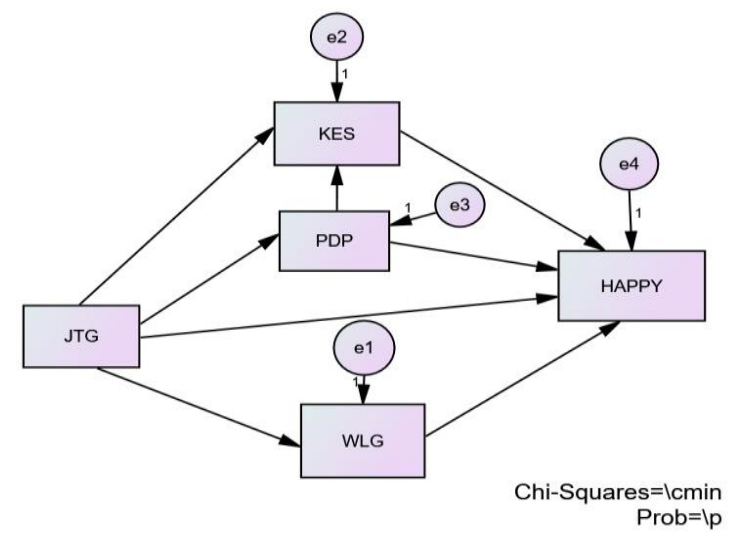

Gambar 1. Diagram Jalur 
Variabel Bebas dan Variabel Terikat

Sumber: Raw data penulis, 2019

Keterangan:

$\begin{array}{ll}\text { JTG } & \text { : Jumlah tanggungan } \\ \text { WLG } & : \text { Waktu luang } \\ \text { KES } & : \text { Kesehatan } \\ \text { PDP } & : \text { Pendapatan } \\ \text { HAPPY } & : \text { Kebahagiaan }\end{array}$

Model yang diajukan dalam analisis jalur adalah sebagai berikut:

$\mathrm{HAPPY}=\beta_{4} \mathrm{JTG}+\beta_{5} \mathrm{PDP}+\beta_{6} \mathrm{KES}+$

$$
\beta_{7} \mathrm{WLG}+\varepsilon_{4}
$$

$\mathrm{PDP}=\beta_{1} \mathrm{JTG}+\varepsilon_{1}$

$\mathrm{KES}=\beta_{2} \mathrm{JTG}+\beta_{8} \mathrm{PDP}+\varepsilon_{2}$

$\mathrm{WLG}=\beta_{3} \mathrm{JTG}+\varepsilon_{3}$

\section{Analisis Kualitatif}

Analisis kualitatif dalam penelitian ini menggunakan metode indepth interview kepada 3 narasumber generasi sandwich. Analisis kualitatif diperlukan untuk menggali informasi yang lebih mendalam terkait tingkat kebahagiaan responden khususnya pada determinan kebahagiaan yang sifatnya abstrak/ tidak terukur dengan angka. Analisis kualitatif juga bermanfaat sebagai bahan konfirmasi dari temuan lapangan yang sudah diolah dan dimodelkan.

\section{HASIL DAN PEMBAHASAN}

Berdasarkan hasil uji statstistik T-test tentang kebahagiaan didapatkan bahwa nilai $P$-value sebesar 0,234 (lebih besar dari $\alpha=0,05)$, artinya tidak ada perbedaan tingkat kebahagiaan antara generasi sandwich dan non-generasi sandwich.

Hubungan antara variabel bebas dengan kebahagiaan secara deskriptif disajikan pada tabel 1 . Tabel 1 juga menyajikan nilai unadjusted odds ratio dari setiap variabel pada generasi sandwich dan non sandwich.

Tabel 1.

Tabulasi Silang Variabel Bebas dengan Kebahagiaan

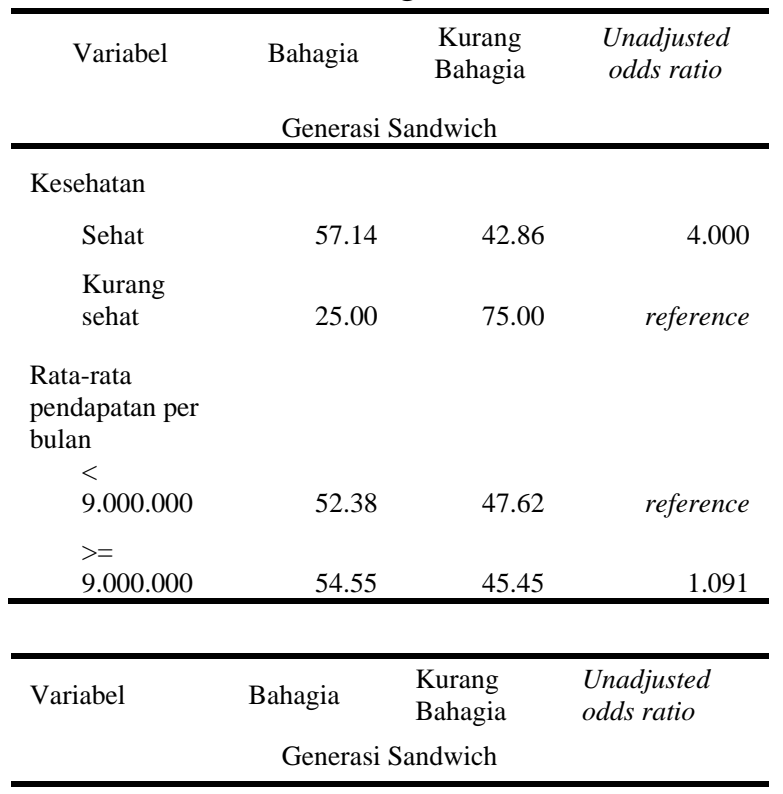

Waktu luang

\begin{tabular}{|c|c|c|c|}
\hline $\begin{array}{l}<=44 \text { jam } \\
\text { dalam } \\
\text { sepekan }\end{array}$ & 60.87 & 39.13 & 1.831 \\
\hline $\begin{array}{l}>44 \text { jam } \\
\text { dalam } \\
\text { sepekan }\end{array}$ & 33.33 & 66.67 & reference \\
\hline
\end{tabular}

Banyak

tanggungan

\begin{tabular}{cccr}
$0-2$ orang & 50.00 & 50.00 & reference \\
$>2$ orang & 54.55 & 45.45 & 1.200 \\
\hline \multicolumn{4}{c}{ Non-Generasi Sandwich } \\
\hline $\begin{array}{l}\text { Kesehatan } \\
\text { Kurang } \\
\text { sehat }\end{array}$ & 53.45 & 46.55 & 2.679 \\
& 30.00 & 70.00 & reference
\end{tabular}

Rata-rata

pendapatan per

bulan

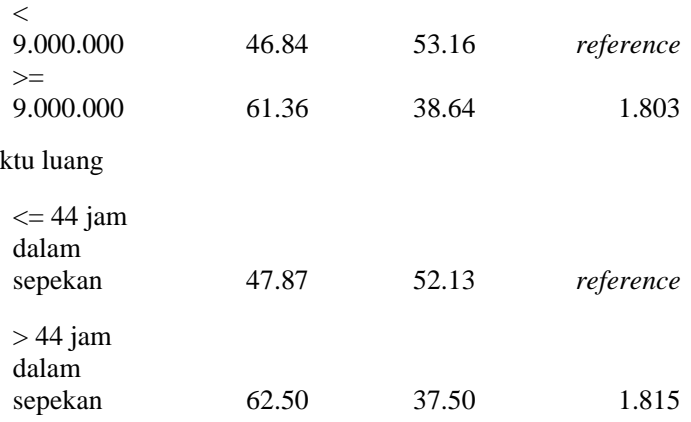


Banyak tanggungan

\begin{tabular}{lllr}
$0-2$ orang & 53.33 & 46.67 & 1.277 \\
$>2$ orang & 47.22 & 52.78 & reference \\
\hline
\end{tabular}

Sumber: Raw data penulis, diolah 2019

Tabel 2 menyajikan temuan estimasi dari analisis jalur. Analisis jalur menjelaskan kontribusi dari tiap variabel bebas terhadap variabel kebahagiaan baik secara langsung maupun tidak langsung. Variabel yang signifikan berhubungan secara langsung terhadap kebahagiaan adalah pendapatan dan kesehatan. Variabel pendapatan secara tidak langsung juga signifikan berhubungan terhadap kebahagiaan melalui channel kesehatan.

Tabel 2.

\begin{tabular}{llr}
\multicolumn{2}{c}{ Temuan Estimasi Analisis Jalur } \\
\hline \multicolumn{1}{c}{ Regresi } & \multicolumn{1}{c}{$\begin{array}{c}\text { Koefisien } \\
\text { Jalur }\end{array}$} & \multicolumn{1}{c}{ t-value } \\
\hline JTG $\rightarrow$ PDP & $-0,099$ & $-0,555$ \\
WLG $\rightarrow$ JTG & $-0,403$ & $-2,450$ \\
JTG $\rightarrow$ KES & 0,246 & 1,549 \\
PDP $\rightarrow$ KES & $0,429 * * *$ & 2,697 \\
KES $\rightarrow$ HAPPY & $0,498 * * *$ & 2,952 \\
JTG $\rightarrow$ HAPPY & 0,022 & 0,128 \\
WLG $\rightarrow$ HAPPY & $-0,136$ & $-0,840$ \\
PDP $\rightarrow$ HAPPY & $-0,452 * * *$ & $-2,722$ \\
\hline$* * * p<0.001$ &
\end{tabular}

Temuan tabulasi silang dan estimasi analisis jalur selanjutnya akan dielaborasi per variabel bebas. Pembahasan ini akan diperkaya dengan temuan indepth interview.

\section{Waktu Luang}

Waktu luang menurut Wang \& Wong (2014) diklasifikasikan menjadi 4 yaitu waktu luang berdasarkan waktu, berdasarkan aktivitas, berdasarkan pemenuhan kepuasan individu dan interaksi sosial, dan waktu luang yang berhubungan dengan kenyamanan dengan pekerjaan dan bidang lainnya. Ada pun waktu luang yang dijadikan pengukuran dalam penelitian ini adalah waktu luang berdasarkan waktu yaitu yang diukur dari waktu di luar jumlah jam bekerja, mengurus rumah tangga, dan sekolah per minggu. Uji hubungan antara variabel kebahagiaan dan waktu luang (dalam sepekan terakhir) dikelompokkan menjadi dua yaitu antara 0-44 jam dan lebih dari 44 jam. Berdasarkan pengamatan, hasil uji crosstab menunjukkan bahwa 60,87 persen generasi sandwich yang memiliki waktu luang 0-44 jam/minggu dalam sepekan terakhir merasa bahagia, sedangkan 39,13 persen merasa kurang bahagia. Sementara itu, dari generasi sandwich yang memiliki waktu luang lebih dari 44 jam/minggu dalam sepekan terakhir, 66,67 persen merasa kurang bahagia dan 33,33 persen merasa bahagia. Sedangkan untuk non-generasi sandwich, 52,13 persen dari mereka yang memiliki waktu luang antara 0-44 jam/minggu dalam sepekan terakhir merasa kurang bahagia, sementara 47,87 persen merasa bahagia. Sementara itu, non-generasi sandwich yang memiliki waktu luang lebih dari $44 \mathrm{jam} /$ minggu dalam sepekan terakhir 62,50 persen merasa bahagia dan 37,50 persen merasa kurang bahagia. Maka, dapat disimpulkan bahwa generasi sandwich yang memiliki waktu luang antara 0-44 jam/minggu dalam sepekan terakhir cenderung lebih bahagia dibanding yang memiliki waktu luang lebih dari 44 jam/minggu. Hal sebaliknya berlaku untuk non-generasi sandwich, di mana mereka yang memiliki waktu luang lebih dari 44 jam/minggu dalam sepekan terakhir cenderung lebih bahagia dibanding yang memiliki lebih sedikit waktu luang.

Berdasarkan unadjusted odd ratio, antara generasi sandwich dan non-generasi sandwich juga menunjukkan hasil berkebalikan. Pada generasi sandwich, sebelum dikontrol terhadap pengaruh dari 
faktor - faktor lain, mereka yang memiliki waktu luang kurang dari 44 jam dalam sepekan terakhir cenderung untuk 1,831 kali lebih bahagia dibandingkan yang memiliki waktu luang lebih banyak dari 44 jam. Sebaliknya, pada non-generasi sandwich, tanpa memandang faktor lain, mereka yang memiliki waktu luang lebih dari 44 jam dalam sepekan terakhir cenderung untuk 1,814 kali lebih bahagia dibandingkan yang memiliki waktu luang kurang dari 44 jam.

Setelah dilakukan analisis jalur, didapatkan hasil P-value sebesar 0,401, di mana nilai tersebut lebih besar dibandingkan dengan $\alpha(0,05)$, sehingga dapat disimpulkan bahwa waktu luang tidak memiliki pengaruh langsung terhadap kebahagiaan. Hal ini turut didukung dengan hasil wawancara indepth interview, seluruh informan merasa bahwa ketersediaan waktu luang tidak lebih penting dalam memengaruhi kebahagiaan mereka apabila dibandingkan dengan kondisi kesehatan, sebagaimana kutipan hasil wawancara indepth interview dengan salah satu informan yang menyebutkan bahwa:

"Menurut saya sih lebih penting sehat dibanding leisure. Leisure yah nanti bisa kapan-kapan".

Hasil penelitian ini tidak sejalan dengan penelitian terdahulu oleh Wang \& Wong (2014) yang menyebutkan bahwa waktu luang memiliki peran penting dalam mempengaruhi kebahagiaan karena waktu luang memberikan individu kesempatan untuk mengurangi stres, bersosialisasi, melatih nilai pribadi dan memenuhi tujuan.

\section{Jumlah Tanggungan}

Uji hubungan antara variabel kebahagiaan dan jumlah tanggungan antara dua generasi dikelompokkan menjadi dua, yaitu mereka yang memiliki jumlah tanggungan keluarga 0-2 orang dan mereka yang memiliki jumlah tanggungan keluarga lebih dari 2 orang. Menurut Shclesinger \& Raphael (1993), salah satu hal yang menjadi ciri utama generasi sandwich adalah jumlah tanggungan keluarga, dimana generasi sandwich menanggung orang tua/mertua dan anaknya, sedangkan nongenerasi sandwich tidak menanggung orang tua/ mertuanya. Berdasarkan hasil crosstab, sebelum dikontrol oleh faktor lain, hasil penelitian menunjukkan bahwa untuk generasi sandwich, mereka yang memiliki jumlah tanggungan lebih dari 2 orang cenderung lebih bahagia (54,2 persen) dibanding mereka yang memiliki jumlah tanggungan kurang dari 2 orang (50 persen). Sementara untuk non-generasi sandwich, mereka yang memiliki jumlah tanggungan kurang dari 2 orang cenderung lebih bahagia (53,33 persen) dibanding mereka yang memiliki jumlah tanggungan lebih dari 2 orang 47,22 persen).

Berdasarkan unadjusted odds ratio, antara generasi sandwich dan non-generasi sandwich juga menunjukkan hasil berkebalikan. Pada generasi sandwich, tanpa memandang faktor lain mereka yang memiliki jumlah tanggungan lebih dari 2 orang cenderung untuk 1,20 kali lebih bahagia dibandingkan yang hanya menanggung kurang dari 2 orang. Sedangkan pada non-generasi sandwich mereka yang memiliki jumlah tanggungan antara $0-2$ orang cenderung untuk 1,28 kali lebih bahagia dibandingkan yang menanggung lebih dari 2 orang.

Sementara itu, berdasar hasil analisis jalur menunjukkan bahwa jumlah tanggungan tidak berpengaruh langsung terhadap kebahagiaan generasi sandwich, yaitu dengan hasil nilai $P$-value 0,898 . Hal ini didukung oleh hasil wawancara mendalam dengan ketiga informan generasi 
sandwich yang menyatakan bahwa banyaknya jumlah tanggungan tidak memengaruhi kebahagiaan yang dirasakan oleh generasi sandwich, berikut adalah hasil kutipan wawancara mendalam dengan informan penelitian:

"Kalau dari orang tua...Kalau orang tua saya ini, enggak, enggak menyusahkan."

Dari jawaban informan di atas menunjukkan bahwa adanya orang tua tidak menjadi beban bagi generasi sandwich. Hal ini tidak sejalan dengan hasil studi Qian \& Qian (2015), Miller (1981) dan Brody (1985) yang mengatakan bahwa beban ganda, tekanan hidup dan stres dengan merawat dan menjaga orang tua yang menua, menyediakan uang, dan memberikan dukungan emosional sepanjang waktu yang kemudian mengurangi kebahagiaan di antara orangorang yang sudah menikah berusia 30-49 tahun. Hasil penelitian ini menunjukkan bahwa orang tua yang tinggal bersama generasi sandwich justru membantu generasi sandwich dalam melakukan tugas dan tanggung jawabnya di rumah, misalnya mengurus anak. Hal ini tergambarkan dari hasil wawancara :

“... pada saat saya capek, orang tua yang langsung pegang anak saya. Saat saya capek, gak kasih mandi, lupa gak kasih makan, gak kasih tidur, langsung rebahan, tau-taunya udah jam 6, saya lupa kasih makan, ternyata saat saya keluar anak saya sudah dimandiin, udah dikasih makan."

Kondisi di atas sejalan dengan pernyataan Ingersoll-dayton, Neal, \& Hammer, (2001) yang bahwa orang tua yang membutuhkan perawatan pun dapat membantu menjaga seorang anak yang telah memasuki usia dewasa melalui berbagai cara.
Temuan bahwa orang tua/ mertua dianggap bukan menjadi beban keluarga dan justru membantu generasi sandwich dipengaruhi oleh faktor budaya. Hal ini disampaikan oleh Schwarz et al., (2010) yang menyatakan bahwa kualitas kepuasan hidup yang dihasilkan pun tidak hanya bergantung pada jenis dukungan tetapi juga pada latar belakang budaya dengan orientasi nilai dan tradisi yang mendasarinya mengenai hubungan antar generasi. Selanjutnya, hasil studi empiris oleh Efklides, Kalaitzidou, \& Chankin (2003) juga menjelaskan bahwa sudah menjadi budaya di Indonesia dan Jerman untuk saling mendukung dan membantu antara generasi (orang tua-anak-cucu).

\section{Pendapatan}

Responden generasi sandwich sebanyak 52,4 persen yang berpendapatan antara Rp.1.000.000,- s.d. Rp.9.000.000,- merasa bahagia dan sebanyak 47,6 persen merasa kurang bahagia. Mereka yang berpendapatan di atas Rp.9.000.000,sebanyak 54,5 persen merasa bahagia dan 45,5 persen merasa kurang bahagia. Sementara itu, responden non generasi sandwich dengan pendapatan Rp.1000.000,- s.d. Rp.9.000.000,- sebanyak 46,8 persen merasa bahagia dan 53,2 persen merasa kurang bahagia. Hal ini berbeda dengan generasi sandwich, dimana walaupun pendapatan kurang dari Rp.9.000.000,- lebih banyak dari mereka yang merasa bahagia dibandingkan dengan mereka yang tidak bahagia. Hasil penelitian ini sejalan dengan Miller (1981) yang menunjukkan bahwa tekanan finansial bukan menjadi masalah utama bagi generasi sandwich. Hasil indepth interview dengan seorang informan juga menunjukkan hal yang serupa, sebagaimana kutipan hasil wawancara, 
"Kalau menurut aku sih (finansial) bukan masalah. Alhamdulillah (finansial) bukan masalah. Jadi yang lebih ke masalah tuh ke culture nya, prinsipnya, pengambilan keputusan, kayak gitu gitu sih."

Jika diamati dari unadjusted odds ratio, maka antara generasi sandwich dan nongenerasi sandwich memberikan hasil dan interpretasi yang sama. Pada generasi sandwich, sebelum dikontrol terhadap pengaruh dari faktor-faktor lain, mereka dengan pendapatan rumah tangga lebih dari Rp.9.000.000,- dalam sebulan cenderung untuk 1,090 kali lebih bahagia dibandingkan dengan yang berpendapatan kurang dari Rp.9.000.000. Pada nongenerasi sandwich, mereka yang pendapatannya lebih dari Rp.9.000.000,dalam sebulan cenderung untuk 1,803 kali lebih bahagia dibandingkan yang berpendapatan kurang dari Rp.9.000.000,-.

Hasil analisis jalur menunjukkan bahwa pada generasi sandwich pendapatan secara signifikan berpengaruh terhadap kebahagiaan, baik secara langsung maupun tidak langsung. Pengaruh secara langsung pendapatan terhadap kebahagiaan sebesar 0,452. Pendapatan memiliki arah yang negatif dalam memengaruhi tingkat kebahagiaan generasi sandwich. Hasil ini menunjukkan hal yang berbeda dengan keadaan umumnya di masyarakat. Dari hasil crosstab antara kebahagiaan dengan pendapatan, menunjukkan bahwa 11 dari 17 responden generasi sandwich yang bahagia memiliki pendapatan di bawah Rp.9.000.000,-. Maka, pendapatan berpengaruh secara tidak langsung terhadap kebahagiaan melalui kesehatan sebesar 0,429, dan pengaruh tidak langsung terhadap cek melalui kesehatan sebesar 0,214. Pendapatan secara langsung memiliki arah pengaruh yang negatif terhadap kebahagiaan tetapi memiliki arah pengaruh yang positif secara tidak langsung melalui kesehatan. Kemiskinan pendapatan secara konsisten berhubungan dengan ketidakbahagiaan dan kesehatan yang dinilai rendah (Subramanian et al., 2005).

Total pengaruh pendapatan terhadap kebahagiaan secara langsung dan tidak langsung adalah sebesar -0,238. Kemiskinan pendapatan secara konsisten berhubungan dengan ketidakbahagiaan (Easterlin, 1995).

\section{Kesehatan}

Responden generasi sandwich yang memiliki kondisi fisik sehat sebanyak 57,1 persen merasa bahagia dan sebanyak 42,9 persen merasa kurang bahagia. Sementara pada generasi sandwich yang memiliki kondisi fisik kurang sehat sebanyak 25 persen merasa bahagia, dan sebanyak 75 persen kurang bahagia. Responden non generasi sandwich yang sehat sebanyak 53,4 persen merasa bahagia dan sebanyak 46,6 persen yang merasa kurang bahagia. Sementara pada non generasi sandwich yang sehat sebanyak 30 persen merasa bahagia, dan sebanyak 70 persen kurang bahagia. Baik generasi sandwich, maupun non generasi sandwich dapat dilihat hasil yang sama, bahwa mereka yang memiliki kondisi fisik sehat lebih banyak yang merasa bahagia, dan mereka yang memiliki kondisi fisik kurang sehat lebih banyak yang merasa kurang bahagia.

Jika di lihat dari unadjusted odds ratio, maka antara generasi sandwich dan non generasi sandwich memberikan hasil dan interpretasi yang sama. Pada generasi sandwich, sebelum di kontrol terhadap pengaruh dari faktor-faktor lain mereka yang sehat cenderung untuk 4 kali lebih bahagia dibandingkan yang kurang sehat. Pada non generasi sandwich, sebelum di 
kontrol terhadap pengaruh dari faktorfaktor lain mereka yang sehat cenderung untuk 2,679 kali lebih bahagia dibandingkan yang kurang sehat. Hasil indepth interview menunjukkan bahwa responden generasi sandwich lebih memilih kesehatan dibandingkan leisure, sebagaimana kutipan hasil wawancara,

"kalau misalnya nggak sehat kita nggak bisa... ehmm kan tanggungannya ada anak nih, apalagi saya kan ibu gitu kan, posisinya perannya. Kalau misalnya saya gak sehat saya gak bisa urus anak-anak saya, di satu sisi orang tua saya, harus kan momong cucu nya nih kalau misal saya gak sehat saya gak bisa bantu juga buat cepet cepet pulang kampus gitu yah.. terus ngasuh anak kayak gitu kan.. gak bisa. Terus udah gitu kalau misalnya gak sehat itu setelah ngurus anak kan harus ada waktu untuk nugas lah kayak gitu kan, itu gak bisa.. jadi menurut saya sih lebih penting sehat dibanding Leisure. Leisure yah nanti bisa kapankapan."

Kesehatan menunjang peran generasi sandwich sebagai orang tua dan anak. Kesehatan yang terganggu membuat generasi sandwich tidak maksimal menjalankan perannya sebagai anak dan orang tua, sehingga menjadikan adanya perasaan bersalah yang berujung pada ketidakbahagiaan.

Hasil analisis jalur menunjukkan bahwa pada generasi sandwich, kesehatan berpengaruh signifikan secara langsung terhadap kebahagiaan sebesar 0,498. Arah pengaruh yang positif menunjukkan semakin baik kondisi kesehatan seseorang, semakin bertambah tingkat kebahagiaannya.

Subramanian et al., (2005) menunjukkan bahwa kesehatan yang buruk berkorelasi positif dengan ketidakbahagiaan, dan berlaku sebaliknya.. Kondisi fisik dan perilaku hidup sehat (konsumsi rendah alkohol, diet sehat, dan tidak merokok) serta keadaan lingkungan dan komunitas yang kondusif juga memiliki andil yang positif terhadap kebahagiaan (, Subramanian et al., 2005; Piqueras et al., 2011, Moor et al., 2014).

Pada penelitian ini, kesehatan memiliki hubungan dan pengaruh yang positif terhadap kebahagiaan. Hal ini berbeda dengan beberapa hasil penelitian lainnya. Diener et al., (2009) menjelaskan bahwa hubungan antara kesehatan dengan kebahagiaan tidak selalu erat dan positif. Ada orang yang sehat tetapi tidak bahagia, sebaliknya ada orang dengan kesehatan yang parah dan dapat menerima kondisi dirinya justru memiliki kebahagiaan yang sama dengan orang yang sehat. Temuan mengenai hubungan antara kebahagiaan dan kesehatan cenderung beragam.

\section{SIMPULAN}

Salah satu temuan menarik pada penelitian ini adalah bahwa di beberapa negara lain, status sebagai generasi sandwich sering kali dikaitkan dengan tingkat stres yang tinggi, namun pada penelitian ini ditemukan bahwa tidak terdapat perbedaan tingkat kebahagiaan antara generasi sandwich dengan nongenerasi sandwich pada sampel penelitian

Lebih lanjut, dari keempat variabel bebas, hanya variabel kesehatan dan pendapatan yang memiliki pengaruh langsung terhadap tingkat kebahagiaan generasi sandwich, sedangkan jumlah tanggungan anggota rumah tangga dan waktu luang tidak berpengaruh secara langsung. Pendapatan yang lebih tinggi dan kondisi tubuh yang sehat cenderung membuat generasi sandwich dan nongenerasi sandwich lebih bahagia. 
Salah satu temuan menarik lainnya pada penelitian ini adalah bahwa tekanan finansial bukan merupakan hal yang dirisaukan oleh generasi sandwich, dan tanggung jawab terhadap orang tua tidak dianggap sebagai beban bagi generasi sandwich. Hasil penelitian menunjukkan bahwa orang tua justru membantu pekerjaan generasi sandwich, salah satunya adalah dalam mengurus anak dan melakukan pekerjaan domestik. Hubungan antara generasi sandwich dengan orang tua pada sampel penelitian (dan berlaku sebaliknya) dipengaruhi oleh budaya yang berlaku di Indonesia, dimana antara generasi saling membantu dan mendukung.

\section{DAFTAR PUSTAKA}

Behavior, S., \& Abdel-Khaled, A. M. (2015). Measuring Happiness with a Single-Item Scale. September. https://doi.org/10.2224/sbp.2006.34.2.139

Broady, T. (2019). The sandwich generation: Caring for oneself and others at home and at work by Ronald J. Burke and Lisa M. Internal Journal of Care and Caring, 307-309. https://doi.org/10.1177/1748895810383807

Brody, E. M. (1985). Parent Care as a Normative Family Stress. Gerontologist, 25(1), 19-29. https://doi.org/10.1093/geront/25.1.19

Bt Ahmad, M., Noorsuriani Bt Maon, S., Naqiuddin Md Mansor, M., \& Mohd Daud, N. (2018). The Academician's Sandwich Generation: Balancing Between Work and Family Through Social Support. The Turkish Online Journal of Design, Art and Communication-TOJDAC, September 1481-1487.

Diener, E., Sapyta, J. J., \& Suh, E. (2009). Subjective Well-Being is Essential to Well-Being. 7965(1998). https://doi.org/10.1207/s15327965pli0901

Easterlin, R. (1995). Will Raising the Incomes of All Increase the Happiness of All ? Journal of Economic Behavior and Organization, 27(1), 35-47.

Efklides, A., Kalaitzidou, M., \& Chankin, G. (2003). Subjective Quality of Life in Old Age in Greece: The Effect of Demographic Factors, Emotional State, and Adaptation to Aging. European Psychologist, 8(3), 178-191. https://doi.org/10.1027//1016-9040.8.3.178

Frey, B. S., \& Stutzer, A. (2000). Happiness, Economy and Institutions. 110, 918-938.

Hernandez, W. R., Marjanen, P., \& Riina, K. (2019). Caring and Sandwich Generation in Finland.

195-243.

https://www.theseus.fi/bitstream/handle/10024/336090/Karki_Marjanen_Hernandez.pdf ?sequence $=1$

Hills, P., \& Argyle, M. (2002). The Oxford Happiness Questionnaire: a compact scale for the measurement of psychological well-being. 33, 1073-1082.

Hopps, M., Iadeluca, L., McDonald, M., \& Makinson, G. T. (2017). The Burden of Family Caregiving in the United States: Work Productivity, Health Care Resource Utilization, and Mental Health among Employed Adults. Journal of Multidisciplinary Healthcare, pp. 10, 437-444. https://doi.org/10.2147/JMDH.S135372

Ingersoll-Dayton, B., Neal, M. B., \& Hammer, L. B. (2001). Aging Parents Helping Adult Children: The Experience of the Sandwiched Generation*. 50.

Juin, S. (2015). Care Arrangements and Caregivers' Health: Should We Care about How they Care? 1-37. 
Marts, S. Z. (2013). Sandwich Generation Caregivers: Ethical Legacies Throughout Generations. Doctoral Dissertations, 48. https://repository.usfca.edu/diss\%0Ahttps://repository.usfca.edu/diss

Migliaccio, J. N. (2019). Millennials - the Newest “ Club Sandwich Generation —” Inherit the "Sandwich Generation." November.

Miller, D. A. (1981). The 'Sandwich' Generation: Adult Children of the Aging. Social Work (United States), 26(5), 419-423. https://doi.org/10.1093/sw/26.5.419

Moor, I., Lampert, T., Rathmann, K., Kuntz, B., Kolip, P., Spallek, J., \& Richter, M. (2014). Explaining educational inequalities in adolescent life satisfaction: Do health behavior and gender matter? International Journal of Public Health, 59(2), 309-317. https://doi.org/10.1007/s00038-013-0531-9

Noor, S., \& Isa, F. M. (2020). Malaysian Sandwich Generation Issues and Challenges in Elderly Parents Care. International and Multidisciplinary Journal of Social Sciences, 9(3), 289-312. https://doi.org/10.17583/rimcis.2020.5277

Piqueras, J. A., Kuhne, W., Vera-Villarroel, P., Van Straten, A., \& Cuijpers, P. (2011). Happiness and Health Behaviours in Chilean College Students: A Cross-Sectional Survey. BMC Public Health, 11. https://doi.org/10.1186/1471-2458-11-443

Qian, Y., \& Qian, Z. (2015). Work, Family, and Gendered Happiness Among Married People in Urban China. Social Indicators Research, 121(1), 61-74. https://doi.org/10.1007/s11205-014-0623-9

Schwarz, B., Albert, I., Trommsdorff, G., Zheng, G., Shi, S., \& Nelwan, P. R. (2010). Intergenerational Support and Life Satisfaction : A Comparison of Chinese, Indonesian, and German Elderly Mothers. https://doi.org/10.1177/0022022110372197

Schlesinger, B., \& Raphael, D. (1993). The Woman in The Middle: The Sandwich Generation Revised. International Journal of Sociology of the Family, 23(1), 77-87.

Solberg, L. M., Solberg, L. B., \& Peterson, E. N. (2014). Measuring Impact of Stress in Sandwich Generation Caring for Demented Parents. 27(4), 171-179. https://doi.org/10.1024/1662-9647/a000114

Subramanian, S. V., Kim, D., \& Kawachi, I. (2005). Covariation in the Socioeconomic Determinants of Self-Rated Health and Happiness: A Multivariate Multilevel Analysis of Individuals and Communities in the USA. Journal of Epidemiology and Community Health, 59(8), 664-669. https://doi.org/10.1136/jech.2004.025742

Varian, H. R. (2010). Intermediate Microeconomics - a Modern Approach (J. Repcheck (ed.); 8th ed.). W. W. Norton \& Company.

Wang, M., \& Wong, M. C. S. (2014). Happiness and Leisure Across Countries : Evidence from International Survey Data. 85-118. https://doi.org/10.1007/s 10902-013-9417-z 